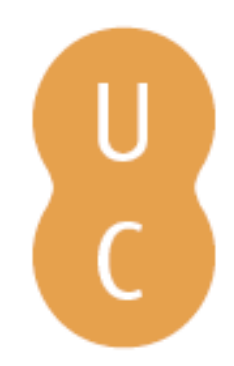

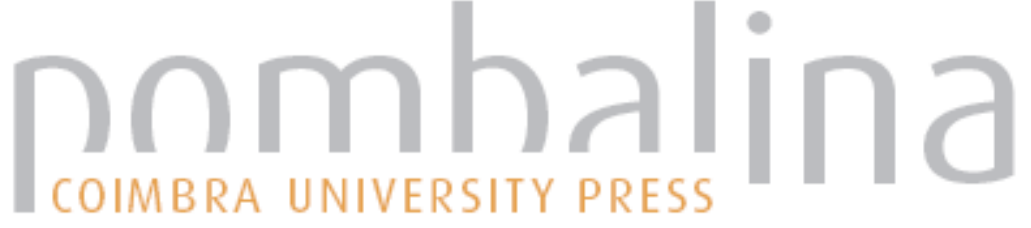

\section{Música e dança na tragicomédia do rei Dom Manuel de António de Sousa (1619)}

Autor(es): $\quad$ Miranda, Maria Margarida Lopes de

Publicado por: Imprensa da Universidade de Coimbra

URL

persistente:

URI:http://hdl.handle.net/10316.2/30037

DOI:

DOI:http://dx.doi.org/10.14195/978-989-26-0567-8_7

Accessed : $\quad$ 26-Apr-2023 01:40:18

A navegação consulta e descarregamento dos títulos inseridos nas Bibliotecas Digitais UC Digitalis, UC Pombalina e UC Impactum, pressupõem a aceitação plena e sem reservas dos Termos e Condições de Uso destas Bibliotecas Digitais, disponíveis em https://digitalis.uc.pt/pt-pt/termos.

Conforme exposto nos referidos Termos e Condições de Uso, o descarregamento de títulos de acesso restrito requer uma licença válida de autorização devendo o utilizador aceder ao(s) documento(s) a partir de um endereço de IP da instituição detentora da supramencionada licença.

Ao utilizador é apenas permitido o descarregamento para uso pessoal, pelo que o emprego do(s) título(s) descarregado(s) para outro fim, designadamente comercial, carece de autorização do respetivo autor ou editor da obra.

Na medida em que todas as obras da UC Digitalis se encontram protegidas pelo Código do Direito de Autor e Direitos Conexos e demais legislação aplicável, toda a cópia, parcial ou total, deste documento, nos casos em que é legalmente admitida, deverá conter ou fazer-se acompanhar por este aviso. 


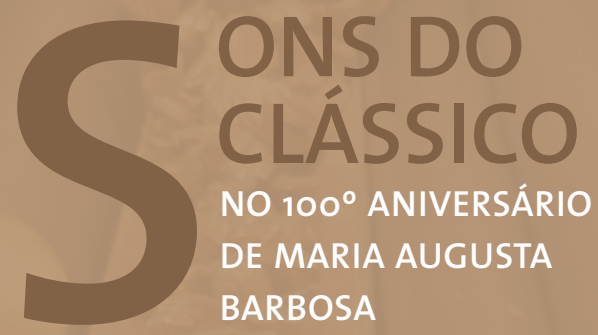

J. M. Pedrosa Cardoso

Margarida Lopes de Miranda COORDENAÇÃO 
Maria Margarida Lopes de Miranda

Centro de Estudos Clássicos e Humanísticos - Universidade de Coimbra

\section{MÚSICA E DANÇA \\ NA TRAGICOMÉDIA DO REI DOM MANUEL, DE ANTÓNIO DE SOUSA (1619)}

\section{Teatro jesuítico em Portugal}

As primeiras obras dramáticas dos Jesuítas em Portugal, nomeadamente em Coimbra e em Évora, inseriam-se não apenas na atividade escolar dos colégios mas também, a outro nível institucional, no âmbito académico superior da própria universidade. Tinham por paradigmas obras de humanistas como Diogo de Teive, Jorge Buchanan e os mestres que precederam os Jesuítas no Colégio das Artes de Coimbra. Por esse motivo, as primeiras peças de teatro são de inspiração profundamente retórica e bíblica, sem deixarem de ser profundamente clássicas e particularmente senequianas.

Não obstante, teatralidade, grandeza e solenidade, riqueza de vestes e profusão decorativa são, desde sempre, uma constante nas descrições de representações escolares do século xvi, diante de uma invariável multidão entusiástica e calorosa.

Veículo da pedagogia humanística e meio de propaganda dos próprios colégios, os espetáculos teatrais eram muito mais do que a ilustração cénica da palavra. Eram concebidos como parte integrante do ensino da Retórica, e deviam por isso obedecer aos preceitos da actio e da pronuntiatio teorizados pelos antigos e retomados pela Retórica de Cipriano Soares de 1562 (sobre as técnicas precisas de voz e de entoação, de expressão de rosto e de movimentos do corpo). As representações teatrais dos jesuítas deviam, além disso, impor-se aos espectadores como verdadeiro espetáculo total, em luxuosos 
aparatos cénicos, com música especialmente composta para a ocasião, numa retórica musical inicialmente subordinada à primazia do texto, de acordo com o que se pensava ter sido a música para o mais autêntico teatro grego. ${ }^{51}$

A participação musical e a intervenção dos Coros dramáticos constitui talvez um dos aspetos mais específicos do teatro dos jesuítas dos primórdios em Portugal, como o próprio Luís da Cruz escreveu no seu prefácio ao leitor (Cruz 1989: 25) e como já tive oportunidade de afirmar em outros estudos (Miranda 2003). ${ }^{52}$ Da tradição humanística de Coimbra, foram pioneiros e ficaram célebres os Coros dramáticos de Diogo de Teive, que celebravam a vitória de David sobre Golias (1550), bem como os Coros da Tragédia de Acab de Miguel Venegas (1562) e da Sedecias de Luís da Cruz (1570). Estes últimos, compostos por D. Francisco de Santa Maria (Pedro Miranda 2005: 131 ss.) e cujos Ms. se conservam parcialmente, têm a originalidade de constituir o mais antigo exemplar conhecido de música para o teatro humanístico.

A intenção originária de revitalização dos modelos greco-latinos e a obrigatoriedade da língua neolatina davam ao espetáculo jesuítico uma feição marcadamente visual, que atraía não só aqueles que tinham capacidade para compreender as longas récitas, mas também os populares que, no dia das representações, enchiam o pátio do colégio. A representação dramática que será objecto deste estudo é, portanto, o culminar de uma tradição longamente estabelecida no nosso país.

\section{A Tragicomédia do Rei Dom Manuel (1619)}

Uma das mais notáveis e mais conhecidas representações jesuíticas de sempre foi a que se realizou em 1619, no Colégio de Santo Antão, em Lisboa,

51 Graças ao Centro de Estudos Clássicos e Humanísticos da Universidade de Coimbra, algumas dessas composições ainda inéditas e conservadas na Biblioteca Geral da Universidade de Coimbra foram já executadas em recital e registadas pelo Grupo Vocal Ançã-ble, no CD Retórica Musical e Música Retórica apenso ao volume Retórica e Teatro: A palavra em acção Porto, 2010, nomeadamente alguns Coros dramáticos por ora considerados os mais antigos do género musical dramático na Europa (séc. xvi). A esse respeito vd. Pedro Miranda (2005) e Margarida Miranda 2006: 299-332.

52 Muitos são os motivos que unem o drama jesuítico ao melodrama. Vd. Morelli e Sala 1994. 
para receber a visita de Filipe III de Espanha a Portugal: a Tragicomédia do Rei Dom Manuel, ou Tragicomédia da Descoberta e Conquista do Oriente, do jesuíta António de Sousa (Mimoso 1620). Tudo foi composto e preparado em menos de 25 dias, diz o prefácio de Sardinha Mimoso, autor do relato mais completo (latino curiosoque lectori): desde o plano inicial até à composição do texto, seguida da distribuição dos papéis aos actores e aos músicos. Mesmo assim, a representação estendeu-se ao longo de dois dias e foi considerada sem rival em qualquer corte europeia. Foi um dos momentos mais altos do programa festivo que celebrou a primeira visita régia à capital lusa sob o domínio filipino, cujos acontecimentos foram encomiasticamente relatados por mais de trinta autores (Alves, 1986: 50-67 e Alenda, 1903: 193-202).

A visita, contra o parecer do Conselho do Estado e do Conselho de Castela, dava-se trinta e cinco anos depois de o monarca ter sido investido como herdeiro do trono de Portugal. Ora, uma das petições que os portugueses acalentavam consistia em tornar Lisboa capital do reino lusoespanhol. O acolhimento ao Monarca deveria pois demonstrar a dignidade de uma grande metrópole, demonstrar o poder e a riqueza de uma grande nação que era a rainha da Europa, protagonista de uma história heroica sem precedentes. Assim se explica a escolha do tema da Tragicomédia e o tom de exaltação patriótica, inspirada na história pátria e nas descobertas e conquistas do Oriente.

Embora não houvesse então uma Corte em Portugal, a Tragicomédia do Rei Dom Manuel era concebida à semelhança dos espetáculos de Corte europeus, e parecia ser o non plus ultra de uma já longa tradição de sumptuosidade e grandeza que caracterizava os palcos jesuíticos portugueses. Nela figuravam mais de 300 personagens, com um guarda-roupa de uma riqueza oriental deslumbrante, carregado de pedras preciosas: mil e noventa diamantes, três mil pérolas, duzentas e quarenta e oito esmeraldas, mil cento e trinta e nove rubis, antigos brocados históricos, sedas raras e adereços preciosos emprestados pelas casas mais fidalgas, pelas igrejas e pelos mosteiros. Duas mil e oitocentas pedras adornavam a figura alegórica de Lisboa e duas mil duzentas e cinquenta, a Alegoria da Piedade. Até uma espada que pertencera a D. João II viera dar maior dignidade à representação. A cenografia e a 
coreografia eram magníficas e a complicação da maquinaria excedia tudo o que até então se havia visto. ${ }^{53}$

À amplificação do espetáculo associaram-se não só a recitação e a dança, mas também as artes plásticas, a arquitetura, o canto e a música, para produzir aquilo a que hoje chamaríamos um espetáculo total, como só uma imaginação barroca poderia conceber.

\section{Prólogo e Ato I}

Música instrumental foi o que deu início ao espetáculo propriamente dito, no dia 21 de Agosto de 1619. Quando a família real chegou ao Colégio e tomou assento, houve um alegre aplauso entre os circunstantes, con salva de musica de chirimias y atabales y, sossegado o auditório, se empeço la obra.

Assim, aliás, fora o rei saudado, à chegada ao cais da cidade: além dos músicos que acompanhavam o monarca na própria galera real sumptuosamente decorada, havia barcos músicos igualmente decorados; e os momentos musicais sucederam-se ao longo do cortejo pela cidade, nas cerimónias da Sé e na Rua Nova - sobre o Arco das Fangas da Farinha, utilizado como palco de teatro para que um grupo de cantores, vestidos de canteiros, se exibisse diante do séquito real.

Mas voltemos ao drama. Depois de um Prólogo repartido entre Lisboa, Sintra e o Tejo para dedicar o espetáculo ao Rei e apresentar o tema da tragicomédia, é novamente ao som de música instrumental (de acordados menestriles y atabales) que as personagens se retiram, para dar início ao Ato I (fol. 9).

Apesar da divisão em cinco Atos, não é simples fazer a narrativa da acção dramática, rarefeita que se encontra numa sucessão de quadros alegóricos e de quadros históricos, que suspendem continuamente as fronteiras do real

53 À fonte mais completa que é Sardinha Mimoso (1620), podemos hoje acrescentar alguns comentários mais recentes à representação, feitos por Dietrich Briesemeister (2006), Miranda (2006) e Pires (2010). Sob um ponto de vista mais indireto, centrado sobretudo na entrada régia mas incluindo também a obra dramática de António de Sousa, refira-se também o estudo de Marica Benatti (2008). 
e do onírico para surpreender todos os sentidos do espectador e o arrebatar numa sequência interminável de sugestões e fantasias.

Há, no entanto, um fio condutor responsável pelo conflito, que atravessa toda a representação. Mais do que histórica, a matéria da tragicomédia é mitificação da história. Por isso, vemos personagens alegóricas, como o Culto Divino e a Idolatria, alternarem em cena juntamente com personagens históricas. A Idolatria e seus sequazes conspiram contra os Portugueses e contra a sua missão de difundir o Culto Divino. É esse plano simbólico que move os acontecimentos, dando assim à história portuguesa uma interpretação providencialista. De um lado o Culto Divino, a Fé e a Piedade, de quem são aliados Dom Manuel e os Portugueses; do outro a Idolatria, a Perfídia e a Cegueira, servidas pelos gentios e as forças da Natureza. Assim, o Rei Dom Manuel e os Portugueses foram os eleitos de Deus para levar a Fé ao Oriente, mas têm que enfrentar a oposição dos deuses vãos, da Perfídia e da Cegueira, que conspiram contra eles, com o auxílio da própria Natureza e dos seus elementos.

Peça dramática tipicamente barroca, a Tragicomédia de Dom Manuel não estava sujeita à precisão dos cânones literários aristotélicos. Podia incorporar reis e heróis mas também alegorias e divindades clássicas, diabinhos e personificações dos elementos da Natureza, personagens de estatuto elevado ou humildes pastores, índios e negros, dando lugar à maior profusão de tons, de estilos de cenários.

Saudado o Monarca e o seu séquito, e dedicado o espetáculo a Sua Majestade, no Prólogo, tem início o Ato I, desde logo com uma notável pluralidade de espaços e de cenários, como descreve Sardinha Mimoso no início da sua $R e$ laçam (fol.3). Num proscénio construído à semelhança dos edifícios teatrais romanos e decorado com colunas, cornijas, frisos e arquitraves revestidos de damascos às cores, havia duas portas: do lado direito entrava e saía o Rei Dom Manuel e todas as personagens que diziam respeito a Portugal; do lado esquerdo, os Mouros e tudo quanto dissesse respeito aos gentios. No nível superior daquela fachada arquitetónica, estava representada a Glória celeste e a hierarquia divina. Dali descia o Anjo da Guarda do Oriente, no meio de uma nuvem formosa; além das duas portas semelhantes às do proscénio antigo, havia ainda dois nichos: um, à direita, continha o trono e o palácio de Éolo, rei dos ventos, de onde haveriam de sair os quatro ventos; outro nicho, 
à esquerda, representava uma boca de Inferno que ora abria ora fechava, vomitando demónios.

Este cenário encontrava o seu paralelo (ou simetria) num grande resplendor de ouro que fingia ser a abertura do céu, por entre um espaço de nuvens e de estrelas delimitado por treze Anjos ao vivo, vestidos de sedas e brocados às cores, com cabeleiras ruivas, grinaldas de flores e instrumentos musicais nas mãos. Este requintado quadro celeste permanecia, porém, oculto por uma espécie de cortinado que era descerrado para revelar subitamente a formosura do espetáculo. E só então os Anjos tocavam os instrumentos que tinham nas mãos. A série de instrumentos que o cronista identifica (começando nos sopros, continuando nas cordas de arco e terminando de novo nos sopros) são um sinal evidente da grande variedade de timbres conjugados e do brilho intencional das peças escutadas: dos baxones, dos violones de arco, dos rabequillas, dos flautas, y otros vários instrumentos músicos (fol. 3).

Não era aleatório o momento em que se descerrava o esplendor da Glória para revelar os Anjos musicantes. Pelo contrário, ele constitui uma das cenas mais emblemáticas da peça. Quando as três alegorias cristãs, o Culto Divino, a Fé e a Piedade, lamentam os estragos feitos no mundo pela Idolatria, abre-se o Céu, correndo as cortinas da representação da Glória, para enviar à Terra o Anjo da Guarda do Oriente. Este desce num pequeno estrado coberto por uma nuvem, por entre os Anjos da corte celestial, ao som da música de variados instrumentos, trazendo na mão uma esfera dourada. Desce até meio da fachada para anunciar ao Culto Divino que em breve será Senhor de todo o Oriente, pois Deus escolheu D. Manuel para essa missão. Depois, desce ainda mais para depor a esfera nas mãos do Culto Divino, o qual por sua vez a entregará nas mãos de Dom Manuel, e retira-se de novo sobre a nuvem em direção ao Paraíso, ao som da mesma música que o havia trazido à terra.

Determinados os acontecimentos pelos desígnios divinos, o Ato I consiste na preparação da viagem ao Oriente - motivada em Dom Manuel por um sonho que ele reconhece ser de inspiração divina. Ao descerrar da Glória com a música dos Anjos celestes sucede simetricamente o rasgar-se dos Infernos, vomitando demónios, dragões e serpentes no palco, por entre nuvens de fogo e fumo negro, acompanhado não já de música mas de um enorme estrondo. 
A missão é então confiada a Vasco da Gama. Enfurecem-se os Infernos, mas os Portugueses rejubilam e representam a primeira folia do drama: às ordens do Tejo, junto de Lisboa e da Serra de Sintra sale una dança de treze pastores de su ribera (...) Dançaron alo pastoril lindamente al sonido de flautas, desafiandose entre si a qual dançava mejor. A primeira dança do drama representa portanto um momento festivo popular de alegria pastoril, encenando uma dança de pastores ao desafio, ao som de flautas.

Por fim, regressa à cena Vasco da Gama, reunindo o piloto e os marinheiros e encorajando-os para a partida. O Ato I termina então com a partida dos Portugueses rumo ao Mar, com uma nau da Índia em palco (de mais de trinta palmos), guarnecida com a cordoaria e equipamento necessários (incluindo a artilharia, cujos disparos ao vivo saudaram o rei). Ouve-se grande gritaria e vozes de marinheiros e é então que um duplo Coro assinala o final do Ato I, dialogando com Vasco da Gama enquanto este navega mar adentro: um Coro de Marinheiros dentro da nau, cantava em português, celebrando a virtude lusitana em versos de quatro sílabas: Fortes Portugueses / Conquistai o mar / Que a terra é pequena / pera triunfar! O seu canto alternava com o canto latino de um outro Coro, constituído por cinco Tritões e quatro Sereias, que permanecia em volta da nau, sobre as ondas encrespadas de um mar que a imaginação do cenógrafo também simulou. Um dos Tritões acompanhava o canto com uma harpa suspensa sobre o mar, outros tocavam baixão (baxon, fol.27) $)^{54}$, enquanto os restantes faziam ouvir a sua voz cantando primeiro 13 , depois 20, depois 25 versos latinos, alternados com o canto dos Marinheiros. Se as intervenções de Vasco da Gama parecem dirigir o canto dos Tritões, o canto dos Marinheiros, em versos extremamente curtos, mais parece concebido ao modo de canto de faina, nomeadamente canto de barqueiros (destinado a ritmar a ação conjunta de remar), que o cronista, na respetiva didascália, designa por celeuma (fol. 28): Exit chorus Trytonum et Sirenum, quem ducit / Gamma naui Indica uectus. / Trytonum cantibus admiscetur Nauticum, Celeuma (Sai um Coro de Tritões e de Sereias, conduzido por Gama numa nau da Índia. Ao canto dos Tritões acrescenta-se um canto de marinheiros, celeuma).

\footnotetext{
54 Na tradição portuguesa, o Baixão refere-se a um instrumento de sopro, de palheta dupla, da família das charamelas, antepassado do fagote. Vd. Alvarenga 1994:112.
} 


\section{Ato II}

No Ato II representa-se a conspiração dos elementos da Natureza contra os navegantes portugueses, com o auxílio do Oceano, aliado da Idolatria.

A Terra, o Ar, a Água e o Fogo, magnificamente caracterizados, tanto quanto uma imaginação barroca servida pelos melhores recursos técnicos podia conceber, escutam a indignação do Oceano, e cada um parte a convocar os seus sequazes contra as naus dos Portugueses, enquanto a Idolatria e suas companheiras exprimem em palco a raiva e a fúria que sempre as caracterizam (fol. 35). Com a Terra, vêm os Promontórios, entre os quais o Cabo da Boa Esperança; com a Água, majestosamente sentada sobre uma orca que lança água e peixes vivos, vêm os monstros marinhos; ao lado do Ar e de Iris, apresentam-se Éolo e os restantes ventos, vindos do seu palácio; e com o Fogo vem o Raio, as Chamas, o Relâmpago e os Cometas. Certas da sua vitória, as forças da Natureza unem-se então para executar uma dança, a dança dos quatro elementos com seus servos, a sugerir a dança dos astros no orbe terrestre (fol. 40 e 42). De poderoso efeito cénico, nela sobressaía de modo particular a caracterização exterior das figuras, o artifício e variedade surpreendente dos trajes, fiéis à iconografia clássica descrita pelos poetas. ${ }^{55}$ Fue dança sobre manera artificiosa, por los enredos com que tan diuersos trajes y formas de monstros al mismo compas dançavan, sin perder punto unos perante los otros (fol. 40).

Depois da dança dos Elementos, de enorme poder simbólico, retiram-se as personagens e o argumento regressa ao plano real e humano: é a vez de impressionar os ouvidos com a gritaria de marinheiros e o grande estrondo da tempestade que as forças cósmicas fizeram abater sobre os portugueses. Sobe então ao palco um Marinheiro para relatar ao próprio Rei os grandes trabalhos e tempestades com que Vasco da Gama conseguiu enfim atravessar o Cabo da Boa Esperança e prosseguir viagem.

\footnotetext{
55 Tritão e o Oceano guardam semelhanças evidentes com as figuras representadas por Camões nos Lusíadas (VI, 16-17), inclusivamente quanto aos termos da descrição, mas é o próprio Sardinha Mimoso que regista essa semelhança, quando descreve o Oceano rei das águas, tal le fingen los poetas; e Tritão como el poeta Camões le pinta mancebo grande y feo Trompeta de su padre y su correo (Fol. 31).
} 
De novo no plano divino, a Idolatria e as forças demoníacas derrotadas lamentam-se do seu insucesso e preparam novos assaltos aos portugueses.

O Coro II, totalmente em língua latina, é executado por uma personagem sem rosto que aclama os êxitos dos portugueses ao vencerem as forças da Natureza. Tem porém a particularidade de dialogar com a Idolatria e com cada um dos Quatro Elementos - solistas - que lamentam o fracasso dos seus planos.

\section{Ato III e entremez}

Quando a raridade dos diálogos e o enfraquecimento da acção dão lugar a uma maior procura de espetacularidade, ganham os Coros e as danças maior incidência. É o que acontece no Ato III e no Ato V, de conteúdo inteiramente celebrativo, em que os Coros e as danças ganham uma dimensão mais relevante.

Se no Ato I, os pastores do Tejo tinham celebrado com danças a partida de Vasco da Gama para a Índia, no Ato III são os pastores de Sintra que celebram a sua chegada, com folias de sus músicos serranos (fol. 49). Nove moços galhardos, um com seu tambor, os outros com sistros e guizos (cestros y sonajas), dançavam e cantavam alternadamente (a la camponês, acrescenta o cronista): No mundo que descubristes / Gama, luz de Portugal/ Dizei se vistes / Rei tan venturoso / ou vassalo tão leal. Vasco da Gama apresenta-se então diante de Dom Manuel, trazendo-lhe em desfile o Oriente com as Províncias conquistadas, e o Monarca ordena que se celebrem festas públicas. Àquele primeiro momento de festa popular ingénua e pueril, em que os jovens pastores proclamavam em ambiente de folia, Manuel he sem segundo, segue-se então uma outra dança mais grave e mais vistosa: a dança do Oriente com suas quinze Províncias sumptuosamente representadas, cada uma com suas insígnias e atributos (fol. 50 ss.): Malabar, Arábia, Pérsia, Cambaia, Decão, Bengala, Pegu, Malaca, Samatra, Sião, China, Japão, Maluco, Etiópia e Ceilão.

O Coro chefiado pelo Oriente constitui pois o primeiro Coro do Ato III, entendido como Coro de bailarinos: Ducit chorum Oriens suarum Prouinciarum (fol. 57). Sardinha Mimoso nada diz sobre a música desta dança solene, 
referindo-se apenas brevemente à sua coreografia (fol. 52) que designa por dança da morte real, com as Províncias dispostas em três fileiras, erguendo ao alto os seus atributos umas para as outras. O autor do relato parece, no entanto, aludir a um modelo coreográfico já criado, inspirado na alegoria secular da universalidade da morte, adequado aliás ao desfile de diferentes figuras, como era efetivamente a série de Províncias do Oriente. Certo é, no entanto, que o teatro jesuítico já possuía então uma notável tradição coreográfica. Alguns anos antes, em Nápoles, 1603 e 1604, na representação da Tragédia Crispus, de Bernardino Stefonio, um Coro de bailarinos desenhara uma águia bicéfala, um caduceu e um labirinto, intersectado com uma cruz (Strappini e Trenti, 1998).

Retirando-se Vasco da Gama, ainda no Ato III, recebe Dom Manuel a notícia inesperada da descoberta do Brasil, que vem conferir aos festejos um quadro mais vivo e gracioso para dar lugar a um dos momentos mais singulares do drama: o segundo Coro do Ato III, ou Coro Brasílico. Eis que o Brasil faz sua entrada, montado num crocodilo e ladeado por seis papagaios representados para o efeito, além de um séquito de índios (tapuias e aimorés). Reflexo evidente da curiosidade natural que o continente americano ainda despertava na Europa, os povos índios parecem merecer do jesuíta uma outra simpatia, mais cândida e mais pueril. Um chefe índio acompanhado de doze tapuias e aimorés simulam a nudez por meio de uma veste justa de cor parda. Trazem o corpo e a cabeça enfeitados de penas coloridas e, nas mãos, arco e flechas, baylando y parlando a su modo ao som de maracas feitas de cabaças cheias com pedrinhas. Dançam em círculos e com grande estrondo de pés (fol. 58). Interpelado pela curiosidade do Rei Dom Manuel, o chefe índio diz aos seus que façam uma demonstração das suas artes, dancem e toquem a seu modo. E começa ele mesmo a cantar a solo, acompanhado à viola, no português estropiado que dissera ter aprendido (en la musica y lenguage que ele mismo compuso a su arte), ao que os outros lhe responderam em coro.

Terminado aquele canto, o Coro Brasílico executa ainda nova dança, sempre em círculo, ao ritmo das maracas que o chefe índio dirigia, colocado no centro, enquanto cantava os versos em língua brasílica que sardinha Mimoso transcreveu, lado a lado com a respetiva tradução. Quer na composição do coro brasílico quer nesta, em forma de crioulo, são evidentes as semelhanças 
formais e semânticas destas composições com os tradicionais vilancicos de Natal, de natureza popular. $\mathrm{Na}$ verdade, os índios em palco parecem saudar a presença do rei como quem, nos cantos tradicionais, saudava o Menino Jesus.

Acabado el choro Brasilico se seguia el Latino por no acabar el acto menos graue... (fol. 60). Novo Coro Latino, executado pela mesma personagem sem rosto, põe fim ao Ato III, com um hino a celebrar mais uma vez a coragem dos portugueses.

A primeira jornada da representação que agora termina previa, porém, uma espécie de entremez. Este, se bem que formalmente distinto do drama cuja representação interrompia, era constituído por cantos e danças, dedicados a Filipe III de Espanha pelas mesmas personagens que haviam feito parte do drama: dez foliões cantando em português, com guizos, tambores e pandeiros, saudavam a presença do rei e do séquito real, no meio de grandes acrobacias (fol. 61); vendo que gente blanca salia a hazer fiesta, o Coro Brasílico começa uma nova dança extremamente viva, ao som de um cortiço em forma de tambor. Cantam em português e em tupi, um canto repartido entre os tapuias com seu chefe e os próprios Papagaios (fol. 61-62). Terminada esta exibição, Brancos e Negros executam um Coro duplo: ao Coro dos Brancos, em português, respondem os tapuias em crioulo, com uma música contrafeita (fol. 62) cujas origens o cronista não identifica.

\section{Ato IV}

A representação continua na tarde do segundo dia, com nova oposição ao projeto dos Portugueses - oposição não já situada no plano simbólico, mas no plano histórico. No Ato IV, o Sultão do Cairo ameaça os portugueses com as armas e chama à sua presença o eremita Frei Mauro, para fazer dele embaixador junto do Papa, a fim de que o Sumo Pontífice, temendo as represálias anunciadas, ordene aos portugueses a retirada do Oriente. Frei Mauro vem então à presença de Dom Manuel para lhe comunicar as terríveis ameaças do Sultão, enquanto na Índia, o vice-rei D. Francisco de Almeida enfrenta o exército inimigo, naquela que ficou conhecida como a batalha de Diu (3 de Fevereiro de 1509), representada no palco de Santo Antão. Derrotado, porém, 
o inimigo não desarma; prepara nova emboscada, serve-se da feitiçaria e convoca a Incúria e os demónios do Inferno. Assim se anunciam as dificuldades sofridas pelos Portugueses na viagem de regresso, bem como a morte do Vice-Rei, como forma de compensar o Sultão pela derrota sofrida. E o Ato IV termina com o Coro e cortejo fúnebre de Dom Francisco de Almeida e a sua chegada ao Reino da Glória, onde S. Tomé, padroeiro da Índia, proclama Afonso de Albuquerque sucessor de Francisco de Almeida e o convida à alegria, pois ele continuará a missão de expandir o Culto Divino no Oriente.

O Coro final do Acto IV (fol. 83-85) inscreve-se assim na tradição de Coros fúnebres que, desde as primeiras representações de Miguel Venegas, em Coimbra e no Colégio Germânico, terminavam as representações jesuíticas. ${ }^{56}$ Ducit Pietas Chorum funebrem... O Coro fúnebre de D. Francisco de Almeida, em diálogo com a Piedade, a Fé e o Culto Divino, choram a morte do herói português, até ao momento em que os Céus se abrem de novo e São Tomé anuncia o seu sucessor. Por fim, o Coro fúnebre converte-se num breve Chorus festiuus (fol. 85), que os soldados assinalam com grande salva de trompetas, chirimias y mas instrumentos de fiesta.

\section{Ato $V$ e triunfo final}

Finalmente, no Ato V, assistimos à chegada de uma nau vinda do Oriente, carregada de produtos exóticos, especiarias e diversas riquezas. A nau é recebida pela alegoria de Portugal, enquanto os capitães de D. Francisco de Almeida anunciam ao rei a vitória em Diu. Mas logo de seguida a 'ação' desloca-se de novo para Oriente, para evocar as vitórias do segundo Vice-Rei da Índia.

Como no início do drama, os acontecimentos são expostos a dois níveis: os acontecimentos simbólicos e prodigiosos vêm como que antecipar os feitos históricos dos portugueses e inseri-los numa história providencialista. A Ásia, montada num rinoceronte, comenta com os Rios Indes e Ganges um sonho misterioso segundo o qual um capitão estrangeiro lhe prometera

\footnotetext{
56 Os Coros fúnebres de Miguel Venegas, por sua vez, eram tributários de Diogo de Teive, que precedeu os Jesuítas no Colégio das Artes (Soares, 2010).
} 
libertá-la do jugo maometano. Reconhecendo em Afonso de Albuquerque a figura misteriosa do seu sonho, a Ásia joelha-se a seus pés suplicante. Apesar do retraimento dos seus soldados, o capitão decide travar guerra com Ormuz, e é então que o seu desígnio recebe a confirmação sobrenatural, por meio da visão de uma cruz adorada por uma multidão de Anjos.

Na Tragicomédia de António de Sousa, a batalha de Ormuz surge, portanto, como resposta à súplica da Ásia para ser libertada do domínio maometano. Súplicas semelhantes são endereçadas por Goa e por Malaca, até que Afonso de Albuquerque é de novo recebido em palco, como Senhor do domínio português no Oriente. Em nome do Rei Dom Manuel, manda então erguer uma fortaleza e sobre ela manda colocar uma pedra onde são inscritos os nomes dos heróis portugueses. E a peça termina com um cortejo de triunfo, em que Afonso de Albuquerque entrega a Portugal os reinos conquistados.

Seja como linguagem celebrativa, seja como meio de entretenimento, é no Ato V que a música ganha maior predominância. Quando a nau do Oriente chega por entre as ondas, carregada de fardos canela e de pimenta e outras mercadorias da Índia, os marinheiros vêm cantando, como cantando haviam partido, rumo ao mar, no Ato I. Mas o momento mais relevante é aquele em que a Glória se abre de novo para uma visão sobrenatural, não para enviar o Anjo, mas para mostrar ao Vice-Rei a cruz do próprio Cristo, iluminada por grande resplendor e cercada por uma multidão de Anjos em adoração. A aparição, descrita no fol. 90, consiste na Cruz em movimento, descendo das alturas numa peanha de nuvens, coberta de Serafins, três dos quais simulavam sustentá-la com as suas próprias asas. Desciam-na primeiro e depois erguiam-na pelos ares, para a recolherem por fim na Glória, que logo se encerrava, diante do olhar atónito de Afonso de Albuquerque e os seus setenta soldados, prostrados em terra para adorarem o lenho sagrado. Auditur caelestis concentus et rupta nube apparet Crux. É ao som de música celestial que se abrem os céus para revelar a cruz da Glória, e é ao som da mesma música celestial que eles se encerram, para confirmar a decisão do Vice-Rei. Seria aquele caelestis concentus música instrumental ou música vocal? Ou seriam antes ambas as expressões? O relato de Sardinha Mimoso nada mais acrescenta sobre a música que acompanhou a segunda manifestação da Glória, mas o leitor conserva ainda na memória a descrição do Acto I, 
quando os Céus se abriram pela primeira vez na fachada arquitetónica do proscénio para que o Anjo da Guarda do Oriente descesse a entregar a esfera ao Culto Divino. Foi uma pequena orquestra de Anjos que então se fez ouvir e que incluía, além das tradicionais flautas e outros instrumentos, um conjunto de instrumentos que ia desde os timbres mais graves aos mais agudos: baxones, violones de arco, rabequillas, flautas y otros (fol. 3). O paralelismo de cenas e de maquinismos cénicos implicados permite pensar que seriam formas musicais semelhantes as que apareciam associadas ao mundo celeste, e em ambas a música instrumental parece ser intencionalmente brilhante, tendo alcançado total autonomia.

Depois deste quadro sobrenatural, ficam em cena o jovem Ceifadino, rei de Ormuz, com o seu séquito de dezasseis pajens, e Coieatar, seu tirânico Governador e Conselheiro. Mas a presença dos dois gentios é apenas o pretexto para representar uma nova dança. O Governador parte para a guerra e deixa o pequeno Ceifadino (de doze anos apenas) na companhia dos meninos pajens da mesma idade. Agitant choream Aulici, dum saltant, lê-se no fol. 97. A dança que os pajens de Ormuz executam com seu rei é uma dança exótica e pueril, mas tem características militares de matriz oriental, como demonstra o uso dos instrumentos de guerra: os pajens desembainham catanas e movem-se em forma de guerra, dançando a punto (expressão com que por diversas vezes designa a cadência) e recolhendo-se debaixo dos escudos, descreve Sardinha Mimoso (fol. 96)

Luego hazen sus juegos y danças a la manera de su pátria, sacando a compas las catanas de sus vaynas y haziendo alegres mudanças, en forma de guerra, lo qual hazian com lindo ayre, y gracia, saltando a punto, y recogiendose debajo sus escudos (fol. 96).

O bailado, de cuja música também nada se diz, termina ao som das trombetas portuguesas que já anunciavam a batalha. Fazendo muralha com as suas catanas e escudos, os pajens rodeiam então o jovem Ceifadino e todos se retiram do palco.

Depois de representar em cena o cerco à cidade (fol. 98), a luta corpo a corpo de mais de sessenta soldados ao som de trombetas e tambores, sob o 
estrondo de verdadeiros projéteis, no meio do verdadeiro odor da pólvora e com disparos de artilharia contra a muralha (o proscenium), o episódio termina com o preito de vassalagem do próprio rei Ceifadino - expulso o seu tirânico governador - ao rei Dom Manuel, seguido da conquista das cidades de Goa e Malaca, conforme estas haviam pedido. O exército português abre mesmo uma brecha na muralha, e nela ergue a bandeira da paz (fol. 102: displodit fistulam Lusitanus, in muro pacis uexillum erigitur).

Se estivéssemos num drama de argumento, a vitória de Afonso de Albuquerque preencheria de imediato a cena final do drama, mas o espetáculo não prossegue sem outro momento musical igualmente integrada no drama: o Coro dos Canteiros (Lapicidae), que Sardinha Mimoso descreve no fol. 107 - 109: Lapicidae canentes marmor expoliunt (fol. 108).

Com los escopros, cinzeles y picos, hazian en la piedra agradable sonido a compas que les servia de instrumento acordado a que cantavan la letrilla que va abaxo, dando muchas bueltas al rededor, y haziendo agradables mudanças al son de su musica (fol. 107).

Os termos da descrição sugerem mais um canto de faina, dirigido pelo bater das próprias alfaias na pedra. Os Canteiros a quem Afonso de Albuquerque manda esculpir os nomes dos heróis portugueses fazem-no cantando redondilhas menores (fol. 109), ao ritmo do seu próprio escopro e cinzel, em movimentos de dança, repetindo o estribilho Porque nos cansamos / em pedra lavrar.

Terminada esta cena, encaminha-se o espetáculo para o seu final, com o triunfo de todas as personagens, organizado em dois cortejos e não um. O primeiro cortejo corresponde ao plano histórico e às personagens humanas; o segundo refere-se ao plano sobrenatural da ação e às personagens divinas. Como num triunfo romano, à frente do exército vêm os prisioneiros de guerra. Segue-se o Tejo, com os seus pastores, e a serra de Sintra com os seus foliões, todos em alegre festa. Depois vem a nau da Índia, cercada de Sereias e Tritões, cantando a choros com os marinheiros. À frente do Oriente ia o cortejo das quinze Províncias, que repetiu a sua famosa dança com os seus atributos (cena XVI), e o mesmo fez o jovem Ceifadino, com seus pajens 
vestidos à mourisca. Juntaram-se-lhes os Canteiros de Afonso de Albuquerque, cantando os louvores de Portugal ao som dos seus instrumentos, e por fim o Brasil:

No quiso el Brasil quedarse fuera del alegre y magnifico triunfo, y sentado en su crocodilo, truxo sus Tapuias y Aymores, com los papagayos en medio, y detrás el Capitan que truxo la nueva del Brasil descubierto (fol. 113).

Como anteriormente, no Ato III, a entrada dos Índios do Brasil no cortejo é representada na sua mais autêntica espontaneidade. É por sua própria iniciativa que se associam, como expressão da inocência e pureza que o dramaturgo lhes atribui. Após eles, seguiam os Capitães portugueses do Oriente, Vasco da Gama, Francisco de Almeida e Afonso de Albuquerque, com coroas de louro como os vencedores Antigos, para entregar a Portugal todos os Reinos e Províncias do Oriente conquistados.

Após este primeiro cortejo histórico, um segundo cortejo traz à cena as figuras alegóricas do drama para representarem a apoteose de Portugal sobre um carro triunfal. Diante do Monarca visitante (Filipe III de Espanha) desfila Portugal em seu carro, puxado por um elefante, um rinoceronte, um tigre e um leão. Com a Ásia por cocheiro, também Portugal trazia os seus simbólicos prisioneiros: a Idolatria, a Cegueira, a Perfídia e os demónios, juntamente com as figuras dos Elementos que haviam conspirado contra os portugueses, os sequazes do fogo e da Água, os monstros marinhos, os Promontórios, os feiticeiros e os sacerdotes pagãos, e até os animais terríficos aludidos no drama (o cão Cerbero, a Salamandra e as Águias). Enquanto os elementos do primeiro cortejo, histórico, soltavam vivas e aclamações ao som da música de instrumentos, todos estes seres alegóricos, por seu lado, faziam ouvir apenas os seus lamentos, gemidos e tristes vozes.

Chegando então Portugal junto de Sua Majestade (Filipe III de Espanha), desce do seu carro triunfal e oferece-lhe as vitórias de seus filhos. Depõe a coroa que levava na cabeça e entrega-lhe os ceptros que levava na mão (em sinal dos cinquenta e sete Reinos do Oriente), com o pedido de que leve adiante aquilo que seus avós tão prosperamente começaram (fol. 114). Não é 
demais realçar a riqueza simbólica de um gesto como este. A ironia histórica é evidente, sobretudo se tivermos em conta o abandono a que ficaram sujeitos os territórios portugueses de além-mar, expostos à cobiça de holandeses e franceses durante o domínio filipino, sob o olhar indiferente da coroa.

O triunfo final estende-se ao longo das cinco últimas cenas (XIV a XVIII), para que cada pequeno coro faça de novo a sua entrada, até que em palco ficam apenas Portugal e o seu império (Ásia, Goa e o Rei de Ormuz, o Brasil e os Índios) dialogando em verso com um Coro Triunfal que eleva o sentido da história de Portugal ao afirmar que a nação recusa o triunfo mortal em nome do divino, mais digno de louvor (mortalem renuens quaeret Olympicum / Laude triumphum).

\section{Conclusão}

Do ponto de vista da realização do espetáculo, a profusão de pedras e tecidos preciosos (pérolas, esmeraldas, rubis, brocados históricos) e outros raros adereços, na caracterização das personagens, corresponde à variedade e omnipresença da música e da dança, desde a conceção original. Por outro lado, a diversidade de géneros musicais acompanha naturalmente a diversidade de ambientes recriados: a música celestial dos Anjos do Paraíso, a vozearia dos marinheiros remadores, o canto sereno dos canteiros ao som de escopros e cinzéis, o canto fantástico de Sereias e Tritões, o canto rude de tapuias, aimorés e papagaios, o canto espontâneo e simples dos pastores, a música exótica dos pajens de Ormuz, o canto fúnebre por D. Francisco de Almeida e o canto celebrativo das glórias dos portugueses.

Ao contrário da teoria dramática de Luís da Cruz que, fiel à maneira Antiga, recomendava que o Coro representasse uma personagem (coletiva), o Coro na Tragicomédia do Rei Dom Manuel encarna múltiplas personagens e assume papéis tão diversificados como fragmentários. Outras vezes, precisamente no lugar canónico do Coro (no final de cada Ato), este parece não corresponder a personagem alguma, sendo executado por uma personagem sem rosto que dialoga com determinadas personagens do drama. Se o final do Ato I é preenchido por um duplo Coro bilingue (um de Tritões e Sereias e 
outro de Marinheiros), os Coros do final do Ato II e III parecem não pertencer ao drama e limitam-se a cantar, em versos latinos, os feitos dos portugueses. $\mathrm{O}$ mesmo acontece com o Coro triunfal do Ato $\mathrm{V}$, que dialoga versos latinos com a Ásia, Goa, o Rei de Ormuz, o Brasil e os Índios. Só o Coro do Ato IV, correspondendo ao cortejo fúnebre de D. Francisco de Almeida, pode ser vagamente identificado com os soldados portugueses, como acontecia com outros Coros semelhantes da tradição dramática jesuítica - mas nada mais é dito a esse respeito.

Na verdade, no espetáculo barroco, os Coros finais não têm a importância dramática que Luís da Cruz lhes atribuía, quando escrevia o seu prólogo ao leitor. Na Tragicomédia do Rei Dom Manuel, eles diluem-se num conjunto de momentos musicais de muito maior efeito, quando associados à complexidade das coreografias e da cenografia, como é o caso do Coro de Tritões e de Sereias ou do Coro dos Marinheiros durante a navegação da nau da Índia sobre as ondas, ou a dança do Oriente com as suas províncias, ou ainda a dança militar de Ceifadino com seus pajens, bem como a dança dos Elementos da Natureza, no Ato II.

O Coro de tapuias e aimorés, que aparece por diversas vezes em cena, carregado de cor local, teria certamente muito mais impacto visual sobre o público do que os Coros convencionais do final do Ato II e III. E o mesmo se pode dizer da música celestial que acompanhou o descerrar da Glória, primeiro para trazer à terra o Anjo da Guarda do Oriente, depois para revelar a visão sobrenatural da Cruz de Cristo. Ela corresponde a um género musical puramente instrumental, sinal inequívoco da maturidade que a instrumentação já havia alcançado. E não é indiferente que o dramaturgo tenha associado essa novidade do género a um momento dramático deliberadamente epifânico.

Sobre a autoria da composição dos Coros, Sardinha Mimoso dá-nos uma informação bastante sumária, mas que não contradiz a prática tradicional dos Actos públicos dos Colégios, que consistia em chamar a colaborar com o Colégio, artistas locais do melhor nível: Los Choros de musica fueron de los mejores Maestros desta profession que ay en Lisboa... (Prefácio Al Curioso Lector). Diversos testemunhos da prática musical e dramática dos Colégios em Portugal, ao longo da segunda metade do século xvi, apontam efetivamente nesse sentido (Miranda 2006a). 
O mesmo se pode dizer dos respetivos intérpretes, que eram músicos chamados pelos padres, ou mesmo oferecidos pelos benfeitores dos Colégios, para solenizar os Atos. A alusão, no prefácio latino, à distribuição das partes entre atores e músicos sugere a especialização destes últimos, como aconteceu, por exemplo, com os cantores dos Coros da Tragédia de Acab, representada em Coimbra em 1562. O mesmo indício está presente na referência explícita de Sardinha Mimoso aos menestréis que executaram a música que despediu as personagens no fim do Prólogo (fol. 9). Músicos seriam também os responsáveis pela execução do caelestis concentus que acompanhava o descerrar da Glória para a visão do Anjo e a visão da Cruz, no meio da maior variedade de instrumentos.

A colaboração de músicos profissionais na composição e na execução do espetáculo não impedia porém os colegiais e o dramaturgo de recorrerem a processos de contrafactum, permitindo que a produção de certos textos musicais partisse de outro texto precedente, num fenómeno de intertextualidade não raro na poética literária, que podia estender-se à poética musical. No entanto, na Tragicomédia do Rei Dom Manuel, os contrafacta reduzem-se aos cantos dos tapuias, no entremez que sucede ao Acto III, e provavelmente, o canto dos mesmos no interior do Acto III, em que as saudações ao rei são feitas ao modo dos vilancicos. Trata-se, sem dúvida, de canções novas, criadas sobre o modelo formal - métrico e musical - de canções tradicionais anteriores, conhecidas pelos atores e pelo público (Pedrosa 2004; Enterria 1995).

Contínuo de quadros de grande impacto sensorial, a Tragicomédia do Rei Dom Manuel apresenta uma multiplicidade de Coros que entram e saem de cena sem outra intenção dramática que não seja a de impressionar vivamente todos os sentidos do público. A fantasia alegórica representada diante de Filipe III de Espanha revela uma complexidade cenográfica e coreográfica inacreditável. O efeito de certas cenas de maquinaria (com as inevitáveis elevações 'em voo', como as aparição do Anjo e da Cruz), ou a cena dos Infernos vomitando fumo e demónios, ou o assalto à muralha de Ormuz, bem como a navegação da nau da Índia por entre as ondas, indicia um grau de técnica espetacular extraordinariamente elevado (Granja 1982 e 1995). E se houve apenas vinte e cinco dias para preparar o espetáculo, é porque os principais instrumentos técnicos eram já conhecidos da cenografia jesuítica, isto é, o 
Colégio podia recorrer a técnicas teatrais já testadas, tributárias de toda uma tradição artística anterior.

Cenografia e coreografia reproduziam os cânones figurativos da pintura barroca e traziam ao palco a incarnação das pinturas fantásticas de Andrea Pozzo, com o mesmo grau de fantástico, com o mesmo poder sugestivo, com o mesmo impacto visual - alegorias suspensas entre nuvens, aparições, triunfos, apoteoses, Anjos, monstros e demónios. A finalidade didática do teatro passara para segundo plano, para dar lugar à expressão de grandeza e sumptuosidade. Por isso a música, de cujo texto nada mais conhecemos a não ser o texto verbal, não podia deixar de ser a expressão da mesma magnificência. Salvas de trombetas, charamelas, tambores e atabales para os momentos de festa e de apoteose - como na saudação inicial ao Rei, ou no Coro festivo do anúncio da sucessão de Afonso de Albuquerque a Dom Francisco de Almeida; instrumentos de corda e de sopro (harpa e baixão) para a música dos seres míticos do Oceano, os Tritões; plena variedade de instrumentos (variedade de cordas e variedade de sopros) para a música divina dos Anjos e da Glória celeste, como na visão do Anjo e na visão da Cruz; flautas, tambores, pandeiros, sistros (cestros) e guizos (sonajas) para a música popular de pastores - como as folias com que os músicos serranos celebram o regresso de Vasco da Gama, ou a música que acompanha as acrobacias dos dez foliões, no entremez do Ato III.

De resto, toda a composição dramática se inspira no convencionalismo das cerimónias das entradas régias: triunfos, paradas, salvas de tiros, cortejos, música e coros, danças e folias. É a cidade que se veste de festa para celebrar a visita do rei e que se representa a si própria em festa. Ao por em cena as próprias celebrações, a cerimónia mais não faz do que representar a sua própria representação - como acontece no entremez do Ato III e no triunfo final - num excesso de significantes e de significados tipicamente barroco.

O espetáculo jesuítico ganhara assim uma feição marcadamente visual, que atraía não só aqueles que tinham capacidade para compreender as longas récitas em latim, de grande intensidade retórica, mas também os populares que, no dia das representações, enchiam o pátio do colégio.

Para os dramaturgos jesuíticos do século xvi e XVII, tornara-se de facto evidente o princípio da linguagem teatral como multiplicidade de códigos e 
de signos linguísticos e extralinguísticos, inalienável da atual teoria literária e dramática. Assim, a riqueza cenográfica acabou por constituir uma das heranças mais específicas do teatro jesuítico para o teatro barroco europeu.

Uma linguagem cénica cada vez mais elaborada, a tendência crescente para a profusão de elementos decorativos, uma caracterização mais rica, em detrimento de uma caracterização mais simbólica, a experimentação de novas soluções para o tratamento do espaço, a participação crescente da música, os primeiros passos para a construção da ilusão cénica, enfim, o gosto pela sumptuosidade e a magnificência não resultam apenas da vinculação do teatro jesuítico à língua latina e da necessidade de deslumbrar o público, mas também de uma consciência teórica inovadora em relação à maneira de produzir teatro e de seduzir o público. Refiro-me a uma consciência teórica que reconhecia a relação natural existente entre teatro e retórica. Essa relação acabou por fazer com que o canto fosse a suprema actio da voz, e a dança, a suprema actio do corpo. Assim vista, essa consciência teórica não pode ser alheia aos fundamentos da mais característica cenografia barroca.

\section{Bibliografia}

Alenda, Jenaro (1903) Relaciones de solemnidades y fiestas de España, 1903.

Alvarenga, João Pedro de (1994), Fábrica de Sons. Instrumentos de Música Europeus dos séculos XVI a XX. Lisboa, Capital Europeia da Cultura.

Alves, Ana Maria (1988) As Entradas Régias Portuguesas, Lisboa, Livros Horizonte.

Benatti, Marica (2008), Simulacri Imperiali Porthoghese: La „Entrada Real“ di Lisbona del 1619 e la Monarchia Duale. Dottorato di Ricerca in Iberistica, Università degli Studi di Bologna.

Briesemeister, Dietrich (2006), "O Teatro escolar jesuítico e os Descobrimentos Portugueses: António de Sousa e La Real Tragicomedia del Rey Dom Manoel" in Sebastião Tavares de Pinho (Coord.) Teatro Neolatino em Portugal no Contexto da Europa. Coimbra: 127-142.

Chiabó, M.; Doglio, F., ed. (1994), Atti del XVIII Convegno Internazionale I Gesuiti e $i$ Primordi del Teatro Barocco in Italia, Roma, Edizione Torre d'Orfeo.

Cruz, Luís da (1989), O Pródigo. Tragicomédia Novilatina. Prefácio, treslado e notas por J. Mendes de Castro. Introdução e tradução do Prólogo por R. M. Rosado Fernandes, Lisboa.

Ferrer Valls, Teresa (1993), Nobleza y espectáculo teatral, 1535-1622: estúdio y documentos. Universitat de Valencia.

García de Enterría, María Cruz (1995), "Bailes, romances, villancicos: modos de reutilización de composiciones poético musicales”, in María Antonio Vigili Blanquet 
et ali (eds.), Música y literatura en la Península Ibérica: 1650-1750. Valladolid: 169-184.

Granja, Agustín de la (1982), Del teatro en la España barroca: Discurso y escenografia. Granada, Universidad.

Granja, Agustín de la (1995), "El actor en las alturas: de la nube angelical a la nube de Juan Rana”, Cuadernos de Teatro Clásico 8 37-67

Mamczarz, Irene (1994), "La Trattatistica dei Gesuiti e la pratica teatrale al Collegio Romano: Maciej Sarbiewski, Jean Dubreuil e Andrea Pozzo" in M. Chiabó; F. Doglio ed. (1994): 349-388;

Martins, Mário (1986), o Teatro nas Cristandades Quinhentistas da índia e do Japão. Lisboa.

Mcgowan, Margaret M. (1963), L'Art du Ballet de Cour em France 1581-1643, Paris, Centre National de la Recherche Scientifique, maxime 205-227.

Mimoso, Sardinha (1620), Relación de la Real Tragicomédia com que los Padres de la Compañia de Jesus en su Colégio de S. Anton de Lisboa recebieron a la Magestad Católica de Filipe II de Portugal... Impresso en Lisboa por Jorge Rodriguez.

Miranda, Margarida (2003) «Música para o teatro humanístico em Portugal: Dom Francisco de Santa Maria, Miguel Venegas S. I. e o Colégio das Artes de Coimbra (1559-1562)", Humanitas 55 315-340.

Miranda, Margarida (2006a) «Teatralidade e linguagem cénica no teatro jesuítico em Portugal (séc. xvi)» Humanitas 58 391-409.

Miranda, Margarida (2006b), Teatro nos Colégios dos Jesuitas. A Tragédia de Acab de Miguel Venegas S. I. e o início de um género dramático (séc. XVI). Lisboa, Fundação Calouste Gulbenkian.

Miranda, Margarida (2010), "O teatro, o palco e o púlpito na Ratio Studiorum (1599)" in Pereira, Belmiro e Várzeas, Marta (2010) Retórica e Teatro. A palavra em acção. Universidade do Porto: 249-262.

Miranda, Pedro (2005), "Música dramática de D. Francisco de Santa Maria: contexto e génese" in Nascimento, Aires e Barbosa, Manuel de Sousa (Eds.), Luís da Cruz S. J. e o teatro jesuítico nos seus primórdios (1604-2004). Lisboa, Centro de Estudos Clássicos: 123-145.

Morelli, G. e Sala, E. (1994), "Teatro gesuitico e melodramma: incontri, complicità, convergenze," M. Zanardi (ed.) I gesuiti a Venezia, Pádua, 597-611;

Pedrosa, José Manuel (2004), "Las canciones contrahechas: hacia una poética de la intertextualidade oral" in Pedro M. Piñero Ramirez et ali (ed.), De la Canción de amor medieval a las soleares. Actas del III Congresso Internacional Lyra Minima Oral, Sevilla, Universidad: 449-469.

Pereira, Belmiro Fernandes e Várzeas, Marta (org.) (2010), Retórica e Teatro. A palavra em acção. Universidade do Porto.

Pires, Cecília (2010), A Real Tragicomédia do Rei Dom Manuel, de António de Sousa, um modelo de literatura independentista. Tese policopiada, apresentada à Faculdade de Letras da Universidade de Coimbra.

Soares, Nair de Nazaré Castro (32010), Diogo de Teive. Tragédia do Príncipe João. Coimbra, Centro de Estudos Clássicos e Humanísticos.

Strappini, Lucia e Trenti, Luigi (1998), Bernardino Stefonio, Crispus Tragoedia, Roma, Bulzoni Editore, 1998. 